\title{
Perbandingan Keterampilan Intrapersonal dan Interpersonal Berbasis Pendidikan Karakter Siswa Sekolah Dasar Negeri Kasihan Bantul
}

\author{
Akif Khilmiyah \\ Fakultas Agama Islam, Universitas Muhammadiyah Yogyakarta. \\ Email: khilmiyahakif@yahoo.com
}

\begin{abstract}
Students' achievement can be shaped by three types of ability (capacity); academic, vocational and generic (personal ability). It appears that generic ability has predominantly determined students' achievement, and therefore providing nurturing personal abaility is necessary. The objectives of this research are twofold: to study both intra and interpersonal skills of the students; to study similarities and differences the level of intra- and interpersonal skills of the students based on their sex, parent's occupation, the level of class, and the order number of children in the family. The research was carried out in State Basic School of Kasihan, Bantul. The subjects of this research are 79 students in the grade IV, V, VI. This reserach concludes that there are 8 types of intrapersonal skills: self-awareness, selfconfidence, effort to handle self-weakness, responsibilities, openness, assertiveness, self dicision making, effort to hadle stressful, and courage to express personal feelings. The lowest ability is self-confidence, and the highest is the courage to express personal feelings. There 8 types in interpersonal: easy to socialize, helpful, emphaty, tolerance,
\end{abstract}

concern with the environment, harmonious, democratic, paying attention to others, and ability to resolve the conflict. The lowest ability is emphaty or effort to understand the others, while the highest is acting democratically, ability to resolve the conflicts, and to pay attention to the others.

Kata Kunci: Intrapersonal, Interpersonal, pendidikan karakter

\section{ABSTRAK}

Keberhasilan seseorang dalam kehidupan ini ditentukan oleh tiga kemampuan yakni akademik, vokasional, generik (kemampuan personal). Ternyata kemampuan generiklah yang paling berperan dalam menentukan keberhasilan dalam kehidupan, maka pemberian bekal kepada siswa berupa kemampuan personal pembentuk karakter sangat diperlukan. Karena itu tujuan penelitian ini adalah: Mengkaji keterampilan intrapersonal dan interpersonal siswa; dan Mengkaji persamaan dan perbedaan tingkat ketrampilan intrapersonal dan interpersonal siswa dilihat dari perbedaan jenis kelamin, pekerjaan orang tua, tingkatan kelas, urutan anak dalam keluarga di SD Negeri Kasihan Bantul. Jenis penelitian ini adalah penelitian kuantitatif yang bercorak komparatif. Subyek dalam penelitian ini adalah siswa kelas IV, V, VI SD Negeri Kasihan Bantul, sebanyak 79 siswa. Penelitian ini menyimpukan, Ada 8 dimensi intrapersonal yakni sadar diri, percaya diri, menangani kelemahan diri, bertanggung jawab terhadap diri sendiri, membuka diri, tegas, berani mengambil keputusan sendiri, menangani stres, dan berani menyampaikan perasaannya. Kemampuan yang paling rendah pada dimensi percaya diri, sedangkan kemampuan yang paling menonjol adalah dimensi keberanian menyampaikan perasaan pada orang lain. Sementara 8 dimensi interpersonal meliputi mudah bergaul, suka menolong, memahami orang lain, tenggang rasa, peduli 
lingkungan, harmonis, demokratis, perhatian terhadap orang lain, dan trampil menyelesaikan konflik. Dimensi kemampuan yang paling rendah adalah kemampuan memahami orang lain. Kemampuan yang paling menonjol adalah kemampuan berlaku demokratis dan kemampuan menyelesaikan konflik serta kemampuan perhatian pada orang lain.

Kata Kunci: Intrapersonal, Interpersonal, pendidikan karakter

\section{PENDAHULUAN}

Berdasarkan Inpres nomor 1/2010 tentang Percepatan Pelaksanaan Prioritas Pembanguan Nasional Tahun 2010, pemerintah telah memerintahkan pengembangan karakter peserta didik melalui pendidikan di sekolah, melalui dua cara yakni: (1) Melalui penyempurnaan kurikulum dan metode pembelajaran aktif berdasarkan nilai-nilai budaya bangsa untuk membentuk daya saing dan karakter bangsa, (2) Melalui penyelenggarakan uji coba kurikulum dan metode pembelajaran aktif berdasarkan nilai-nilai budaya bangsa untuk membentuk daya saing dan karakter bangsa (Kemendiknas, 2011:243). Kesadaran penanaman karakter di Sekolah Dasar (SD) ini merupakan wujud dari pelaksanaan Tujuan Umum Pendidikan Dasar, dalam KTSP yakni: "Meletakkan dasar kecerdasan, pengetahuan, kepribadian, akhlak mulia, serta ketrampilan untuk hidup mandiri dan mengikuti pendidikan lebih lanjut". "Dengan demikian tujuan sekolah mendidik siswa adalah untuk membentuk karakter, agar tidak saja menjadi manusia yang cerdas secara kognitif tetapi juga memiliki kemampuan afektif untuk mengaplikasikan kecerdasan kognitifnya. Oleh karena itu fungsi sekolah adalah untuk membentuk karakter siswa.

Banyak penelitian menunjukkan bahwa keberhasilan seseorang dalam kehidupan ini ditentukan oleh tiga kemampuan, yakni (1) kemampuan akademik (common core) yang mencakup keberhasilan dalam menguasai mata pelajaran, (2) kemampuan vokasional yang ditunjukkan melalui ketrampilan dalam suatu bidang tertentu, dan (3) kemampuan akademik generik (common knowledge) yang ditunjukkan melalui kemampuan personal (kemampuan mengambil keputusan secara rasional, kemampuan merancang masa depan, dll) serta kemampuan sosial (kemampuan bekerjasama, kemampuan memahami orang lain, dll). ${ }^{2}$ Diantara ketiga kemampuan tersebut, ternyata kemampuan generik paling berperan dalam menentukan keberhasilan dalam kehidupan, dengan kontribusi sekitar 70h. Berdasarkan penelitian tersebut, maka pemberian bekal kepada siswa berupa kemampuan menahan diri, mengendalikan emosi, memahami emosi orang lain, memiliki ketahanan menghadapi kegagalan, bersikap sabar, memiliki motivasi diri yang tinggi, kreatif, berempati, dan bersikap toleran, lebih penting dari sekedar memiliki nilai akademik semata.

Penilaian kepribadian siswa sebagai aspek afektif harus dilakukan secara komprehensif. Pengembangan penilaian kepribadian sebagai ketrampilan afektif siswa meliputi ketrampilan intrapersonal dan interpersonal. Ketrampilan intrapersonal berkaitan dengan pengembangan kemampuan mengelola diri sendiri, sedangkan ketrampilan interpersonal berhubungan dengan pengembangan kemampuan mengadakan hubungan antar pribadi. ${ }^{3}$ Dengan demikian pengembangan penilaian kepribadian siswa meliputi ketrampilan intrapersonal mengarah pada kecerdasan emosional, sedangkan ketrampilan interpersonal mengarah pada kecerdasan sosial. 
Karena itulah penelitian ini menjadi penting dan stragis untuk dilakukan guna mengetahui tingkat ketercapaian kemampuan intrapersonal dan interpersonal siswa pada sekolah Dasar Negeri Kasihan yang dijadikan sebagai tempat uji coba pendidikan karakter oleh Pemerintah Daerah di Propinsi Daerah Istimewa Yogyakarta sejak tahun2010.

Penelitian ini bertujuan untuk: (1) Mengkaji ketrampilan intrapersonal dan interpersonal siswa setelah pelaksanaan pendidikan karakter di SD Negeri Kasihan Bantul. (2) Mengkaji persamaan dan perbedaan tingkat ketrampilan intrapersonal dan interpersonal siswa dilihat dari perbedaan jenis kelamin, pekerjaan orang tua, tingkatan kelas, urutan anak dalam keluarga di SD Negeri Kasihan Bantul. Hasil penelitian ini diharapkan dapat memberikan kontribusi bagi pemerintah dalam mengembangkan karakter siswa melalui evaluasi ketercapaian ketrampilan intrapersonal dan interpersonal berbasis pendidikan karakter di Sekolah Dasar. Disamping itu juga dapat memberikan sumbangan pemikiran dalam mengkritisi dan mentyelesaikan permasalahan pendidikan karakter serta memberikan suatu kerangka acuan alternatif dalam pengembangan penilaian aspek afektif pendidikan karakter di sekolah.

\section{TENTANG PENDIDIKAN KARAKTER}

Pendidikan karakter mempunyai makna lebih tinggi dari pendidikan moral, bukan sekedar mengajarkan mana yang benar dan mana yang salah, tetapi lebih dari itu pendidikan karakter menanamkan kebiasaan (habituation) tentang hal yang baik sehingga peserta didik menjadi paham tentang yang baik dan yang salah (domain kognitif), mampu merasakan nilai yang baik (domain afektif) dan biasa melakukannya (domain perilaku). Pendidikan karakter erat kaitannya dengan pembiasaan yang terus-menerus dilakukan.

Berdasar beberapa pendapat di atas dapat disimpulkan bahwa karakter dapat disamakan artinya dengan akhlak, adalah cara berfikir dan berperilaku yang menjadi ciri khas setiap individu terkait dengan nilai benar salah, dan nilai baik-buruk, sehingga karakter akan muncul menjadi kebiasaan yang termanifestasi dalam sikap dan perilaku untuk selalu melakukan hal yang baik secara terus menerus dalam semua lingkungan kehidupan. Karena karakter terkait dengan nilai-nilai kebaikan, maka pendidikan Karakter adalah upaya yang dilakukan secara bertahap untuk menanamkan kebiasaan, agar anak selalu dapat berfikir, bersikap dan berperilaku berdasarkan nilai-nilai kebaikan, sehingga pendidikan karakter selalu dikaitkan dengan pendidikan nilai. Nilai-nilai yang menjadi ukuran baik buruk dan benar salah adalah nilai moral. Nilai moral tersebut dapat berupa nilai instrumental yaitu presentasi diri, evaluasi, justifikasi dan perbandingan diri sendiri dengan orang lain, ataupun nilai moral terminal, yang secara konsisten telah dimiliki oleh individu, menjiwai tingkah laku dan kebiasaan sehingga menjadi karakter.

Menurut panduan pelaksanaan pendidikan karakter Kemendiknas tahun 2011, karakter diartikan sebagai perilaku yang dilandasi oleh nilai-nilai berdasarkan norma agama, kebudayaan, hukum/konstitusi, adat istiadat, dan estetika. ${ }^{4}$ Pendidikan karakter adalah upaya yang terencana untuk menjadikan peserta didik mengenal, peduli 
dan menginternalisasi nilai-nilai sehingga peserta didik berprilaku sebagai insan kamil. Tujuan Pendidikan Karakter adalah untuk meningkatkan mutu penyelenggaraan dan hasil pendidikan di sekolah melalui pembentukan karakter peserta didik secara utuh, terpadu, dan seimbang, sesuai standar kompetensi lulusan. Adapun sasarannya adalah seluruh warga sekolah, terutama peserta didik sebagai prioritas utama, dan pendidik, berperan sebagai teladan.

Nilai-nilai Basis Pengembangan Karakter meliputi delapan nilai yaitu: Religiusitas, Kejujuran, Kecerdasan, Tanggung jawab, Kebersihan dan kesehatan, Kedisiplinan, Tolong-menolong, Berfikir logis, kritis, kreatif dan inovatif. Nilai-nilai yang perlu diinternalisasikan di Sekolah Dasar ada 25 butir terbagi 5 kelompok yakni (1) Nilai karakter dalam hubungan manusia dengan Tuhan adalah nilai Religius, (2) Nilai karakter dalam hubungannya dengan diri sendiri, meliputi: Kejujuran, Kecerdasan, Rasa tanggung jawab, Kebersihan dan kesehatan, Kedisiplinan, Berfikir logis, kritis, kreatif, inovatif, Ketangguhan, Keingintahuan, Cinta ilmu, Rasa percaya diri, Kemandirian, Keberanian mengambil resiko, Berorientasi pada tindakan, Jiwa kepemimpinan, Kerja keras. (3) Nilai karakter dalam hubungan antar manusia yang meliputi: Tolong menolong, Kesantunan, Kesadaran akan hak dan kewajiban diri dan orang lain, Kepatuhan pada aturan-aturan sosial, Menghargai karya dan prestasi orang lain, dan Demokrasi, (4) Nilai karakter dalam hubungan manusia dengan lingkungan yakni Kepedulian terhadap lingkungan, dan (5) Nilai kebangsaan yang meliputi: Nasionalisme, dan Menghargai keberagaman.

\section{KETRAMPILAN INTRAPERSONAL DAN INTERPERSONAL \\ Ketrampilan Intrapersonal (Intrapersonal Skill)}

Ketrampilan pribadi (personal skill) tidak

hanya berupa ketrampilan intrapersonal tetapi juga ketrampilan interpersonal (ketrampilan memahami orang lain). Sebagaimana dinyatakan oleh Gardner, ${ }^{5}$ bahwa ketrampilan intrapersonal merupakan pengetahuan tentang aspek internal seseorang: akses perasaan seseorang, emosi seseorang, kapasitas diri, dan pemahaman terhadap perilaku diri. Batasan ini menunjukkan bahwa ketrampilan intrapersonal ditandai dengan mengembangkan diri melalui mengendalikan emosi diri, memotivasi diri, bertanggungjawab atas kehidupan sendiri, dan mengembangkan harga diri.

Pendapat di atas dipertegas oleh Daniel Goleman dengan menyatakan bahwa ketrampilan intrapersonal adalah kemampuan yang korelatif, tetapi terarah ke dalam diri. ${ }^{6}$ Dengan demikian ketrampilan intrapersonal merupakan kunci menuju pengetahuan diri. Lebih lanjut dijelaskan bahwa ketrampilan intrapersonal merupakan kemampuan membentuk suatu model diri sendiri yang teliti dan mengacu pada diri serta kemampuan untuk menggunakan model tadi sebagai alat untuk menempuh kehidupan secara efektif. Ketrampilan intrapersonal merupkan akses menuju perasaan-perasaan diri seseorang dan kemampuan untuk membedakan perasaanperasaan tersebut serta memanfaatkannya untuk menuntun tingkah laku. Ketrampilan intrapersonal dapat dikatakan sebagai ketrampilan tentang diri sendiri. Rose dan Nicholl menyatakan bahwa ketrampilan 
intrapersonal merupakan kemampuan menganalisis diri dan merenungkan diri, mampu merenung dalam kesunyian dan menilai prestasi seseorang, meninjau perilaku seseorang dan perasaan-perasaan terdalamnya, membuat rencana dan menyusun tujuan yang hendak dicapai. Hal ini berkaitan dengan kepeduliannya terhadap tujuan yang hendak dicapai. ${ }^{?}$

Secara ringkas ketrampilan intrapersonal berkaitan dengan pemahaman diri sendiri. Mant menyatakan bahwa ketrampilan intrapersonal merupakan kemampuan untuk memahami diri sendiri. Dengan demikian dapat dikatakan bahwa seseorang yang memiliki ketrampilan intrapersonal dapat dengan teliti mengerti apa yang terjadi pada dirinya sendiri. ${ }^{8}$ Pendapat senada disampaikan oleh Lwin et al, bahwa ketrampilan intrapersonal merupakan kemampuan untuk memahami diri sendiri dan bertanggungjawab atas kehidupannya sendiri. ${ }^{9}$ Lebih lanjut Lwin et al, menyatakan bahwa orang-orang yang memiliki ketrampilan intrapersonal tinggi cenderung menjadi pemikir yang tercermin pada apa yang mereka lakukan dan terus menerus membuat penilaian diri. Batasan lebih ringkas disampaikan oleh Ayan bahwa ketrampilan intrapersonal adalah kemampuan memahami perasaan diri sendiri, gemar merenung, serta berfilsafat. ${ }^{10}$ Batasan ini menunjukkan bahwa ketrampilan intrapersonal, yaitu pemahaman tidak hanya terhadap perasaan semata namun juga masalah berfikir.

Untuk mengetahui indikator mengenai ketrampilan intrapersonal, Lazear menyatakan bahwa ketrampilan intrapersonal meliputi pengetahuan tentang perasaan, proses berfikir, refleksi diri dan rasa atau intuisi tentang realitas spiritual. ${ }^{11}$ Cunningham dan Corderio menyatakan bahwa ketrampilan intrapersonal adalah akses terhadap perasaan diri sendiri dan kemampuan untuk membedakan emosi diri, pengetahuan tentang kekuatan seseorang, dan kelemahan seseorang. ${ }^{12}$

Berdasarkan uraian di atas, yang dimaksud dengan ketrampilan intrapersonal adalah ciriciri spesifik yang lebih substantif dari kemampuan seseorang untuk memahami keberadaan dirinya dan berani bertanggung jawab terhadap kehidupan pribadinya sehingga terbentuk kepribadian yang mantap, yang nampak pada: sadar diri, percaya diri, menangani kelemahan diri, bertanggung jawab terhadap diri sendiri, membuka diri, tegas, berani mengambil keputusan sendiri, menangani stres, dan berani menyampaikan perasaannya.

\section{Ketrampilan Interpersonal (Interpersonal Skill)}

Setiap individu mempunyai ketrampilan personal yang berkaitan dengan pemahaman terhadap dirinya sendiri dan orang lain. Ketrampilan interpersonal merupakan pemahaman tentang perbedaan orang lain dengan dirinya sendiri. Dengan pemahaman ini, seseorang dapat memahami aspek-aspek perasaan orang lain. Sebagaimana dinyatakan Gardner bahwa ketrampilan interpersonal adalah kemampuan untuk menyatakan dan membuat perbedaan diantara individuindividu lain, dan khususnya, suasana hati (moods), temperamen, motivasi, serta maksud mereka. ${ }^{13}$

Pendapat di atas dipertegas oleh Goleman (2005:52) dengan menyatakan bahwa ketrampilan interpersonal merupakan kemampuan untuk memahami orang lain: 
apa yang memotivasi mereka, bagaimana mereka bekerja, bagaimana kerjasama yang mereka lakukan. Ketrampilan interpersonal juga merupakan ketrampilan dalam kaitannya dengan hubungan sosial. Rose dan Nicholl (2002:60) menyatakan bahwa ketrampilan interpersonal adalah kemampuan bekerja secara efektif dengan orang lain, memperhatikan empati dan pengertian, memperhatikan motivasi dan tujuan mereka.

Pendapat senada disampaikan oleh Amstrong (1994:3) bahwa ketrampilan interpersonal merupakan kemampuan mempersepsi dan membedakan suasana hati, maksud, motivasi, serta perasaan orang lain. Dengan demikian ketrampilan interpersonal merupakan kemampuan mempersepsi dan membedakan suasana hati, maksud, motivasi, serta perasaan orang lain berdasarkan ekspresi wajah, suara, gerak isyarat orang lain. Ketrampilan interpersonal dapat dikatakan sebagai kemampuan untuk memahami orang lain. Menurut Mant bahwa ketrampilan interpersonal merupakan kemampuan untuk mengetahui apa yang terjadi diantara orang-orang dan memobilisasinya, sebagaimana menjadi guruguru dan penjual yang baik. ${ }^{14}$

Pendapat di atas juga didukung oleh Lazear dengan menyatakan bahwa ketrampilan interpersonal merupakan kemampuan untuk menggunakan komunikasi verbal dan non-verbal, serta kapasitas untuk membedakan orang lain, misalnya, perbedaan suasana hati, temperamen, motivasi, dan maksud. ${ }^{15}$ Dengan demikian, ketrampilan interpersonal ini memungkinkan seseorang untuk mengembangkan rasa empati dan perhatian satu sama lain.
Ketrampilan interpersonal yang dimiliki oleh seseorang dinyatakan berpengaruh terhadap kariernya. Cunningham dan Corderio menyatakan bahwa ketrampilan interpersonal adalah kapasitas untuk melihat dan merespon dengan tepat suasana hati, temperamen, motivasi, dan keinginan orang lain. ${ }^{16}$ Ayan menyatakan bahwa ketrampilan interpersonal merupakan kemampuan memahami orang lain, pikiran, serta perasaan mereka. ${ }^{17}$ Lebih lanjut dijelaskan bahwa ketrampilan ini dapat dilakukan melalui pertemuan dan percakapan dengan orang-orang daerah lain, mengenai kehidupan mereka sehari-hari meskipun tidak menguasai bahasa daerah mereka, berkomunikasi dengan bahas isyarat sudah merupakan tantangan bagi ketrampilan interpersonal itu sendiri.

Sedangkan mengenai pengaruh ketrampilan interpersonal terhadap diri seseorang dijelaskan oleh Lwin et al. sebagai berikut: Ketrampilan interpersonal adalah kemampuan untuk memahami dan memperkirakan perasaan, temperamen, perasaan, suasana hati, maksud dan keinginan orang lain serta menanggapi secara layak. Lebih lanjut dinyatakan ketrampilan interpersonal memungkinkan seseorang untuk membangun kedekatan, pengaruh, pimpinan, dan membangun hubungan dengan masyarakat. ${ }^{18}$

Berdasarkan uraian di atas, yang dimaksud dengan ketrampilan interpersonal adalah ciriciri spesifik yang lebih substantif dari kemampuan seseorang dalam berfikir dan berkomunikasi secara efektif sehingga menimbulkan hubungan saling pengertian antara dirinya dengan orang lain, yang nampak pada: mudah bergaul, suka menolong, memahami orang lain, tentang 
rasa peduli lingkungan, harmonis, demokratis, perhatian terhadap orang lain, dan trampil dalam menyelesaikan konflik.

Untuk mewujudkan manusia yang berhasil dalam kehidupan, diperlukan penilaian yang menyeluruh aspek kognitif dan non kognitif (kepribadian) dengan instrumen pendidikan karakter yang meliputi ketrampilan intrapersonal dan interpersonal. Adapun karakter yang termasuk pada kemampuan psikososial anak terutama pada kecerdasan emosi dan sosialnya meliputi: (1) percaya diri (confidence), (2) kemampuan kontrol diri (selfcontrol), (3) kemampuan bekerjasama (cooperation), (4) kemudahan bergaul dengan sesama (socialization), (5) kemampuan berkonsentrasi (concentration), (6) rasa empati (empathy), dan (7) Kemampuan

berkomunikasi (communication).

Jenis penelitian ini adalah penelitian kuantitatif yang bercorak komparatif. Subyek dalam penelitian ini adalah siswa kelas IV,V,VI SD Negeri Kasihan Bantul, sebanyak 79 siswa. Dan sebagai informan tambahan adalah guru, kepala sekolah dan karyawan.

Tehnik pengambilan sampel dilakukan secara purposive random sampling. Teknik

pengumpulan data yang digunaka adalah: angket, observasi non partisipan, wawancara terpimpin, dan dokumentasi. Analisis data penelitian ini menggunakan statistik deskriptif untuk mengkaji kemampuan ketrampilan intrapersonal dan interpersonal siswa sekolah dasar. Analisis perbedaan antara perbedaan jenis kelamin digunakan uji t (t-tes) dan untuk menganalisis perbedaan berdasarkan pekerjaan orang tua, tingkatan kelas dan urutan anak dalam keluarga dilakukan teknik ANOVA satu arah.

\section{HASIL PENELITIAN DAN PEMBAHASAN Ketrampilan Intrapersonal dan Interper- sonal siswa}

Kemantapan pribadi yang berkarakter akan nampak melalui sembilan indikator ketrampilam intrapersonal. Adapun indikator-indikator ketrampilan intrapersonal yang menjadi fokus dalam penelitian ini meliputi sembilan dimensi yakni: (1) sadar diri, (2) percaya diri, (3) menangani kelemahan diri, (4) bertanggung jawab terhadap diri sendiri, (5) membuka diri, (6) tegas, (7) berani mengambil keputusan sendiri, (8) menangani stres, (9) berani menyampaikan perasaan. Gambaran tentang ketrampilan intrapersonal siswa di SD Negeri Kasihan Bantul dapat dilihat pada Tabel 1.

Data Tabel 1 menunjukkan bahwa semua dimensi ketrampilan intrapersonal siswa SD Negeri Kasihan Bantul menunjukkan gambaran yang cukup merata. Namun jika kita amati lebih jauh selisih antara nilai mean dan standar deviasi dari kesembilan dimensi tersebut . Dengan demikian maka kemampuan percaya diri siswa masih lebih rendah dibanding kemampuan delapan dimensi yang lain. Kemampuan yang paling bagus dimiliki siswa adalah kemampuan mengatasi kelemahan diri, kemudian disusul kemampuan melakukan curhat pada orang lain.

Gambaran tentang ketrampilan interpersonal siswa SD Negeri Kasihan Bantul. Berdasarkan hasil uji dapat diketahui bahwa kesembilan dimensi ketrampilan interpersonal siswa SD Negeri Kasihan Bantul menunjukkan kondisi yang baik, karena kesembilan dimensi memiliki mean yang seperlima lebih besar dari standar deviasinya. Dengan demikian maka kemampuan siswa 
TABEL 1. KETRAMPILAN INTRAPERSONAL STATISTICS

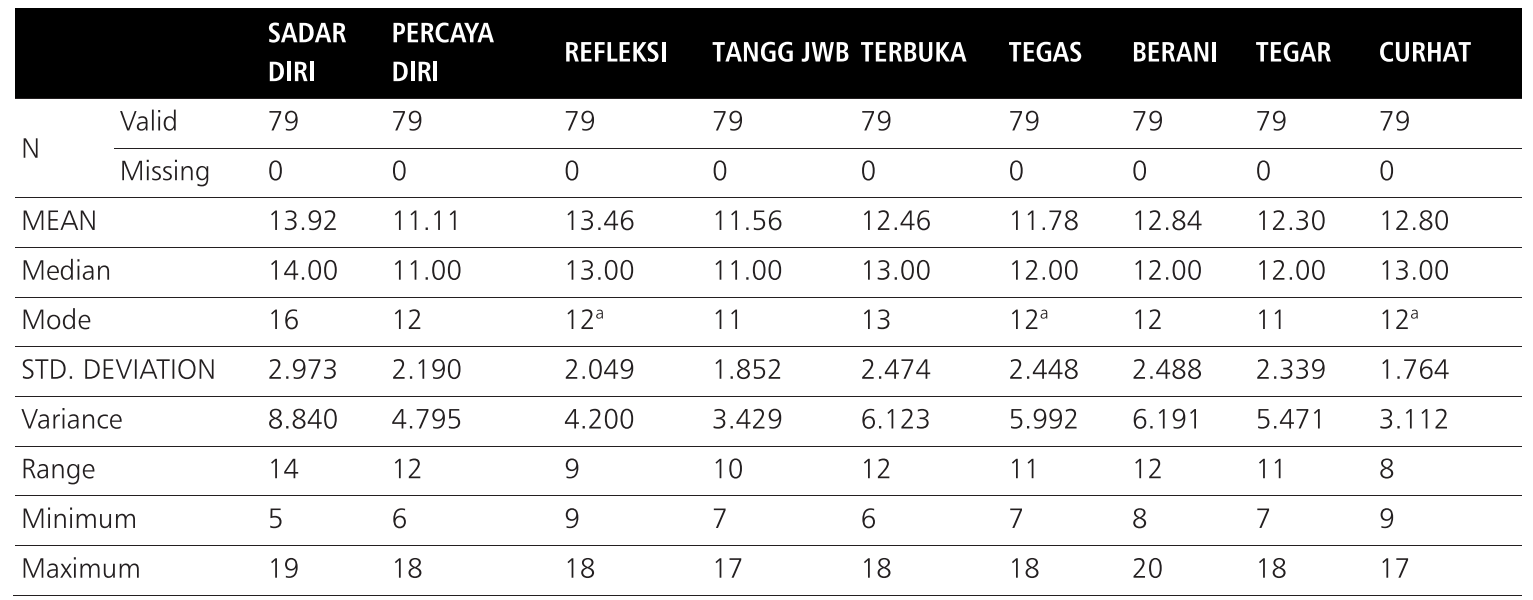

TABEL 2.1. KETRAMPILAN INTERPERSONAL

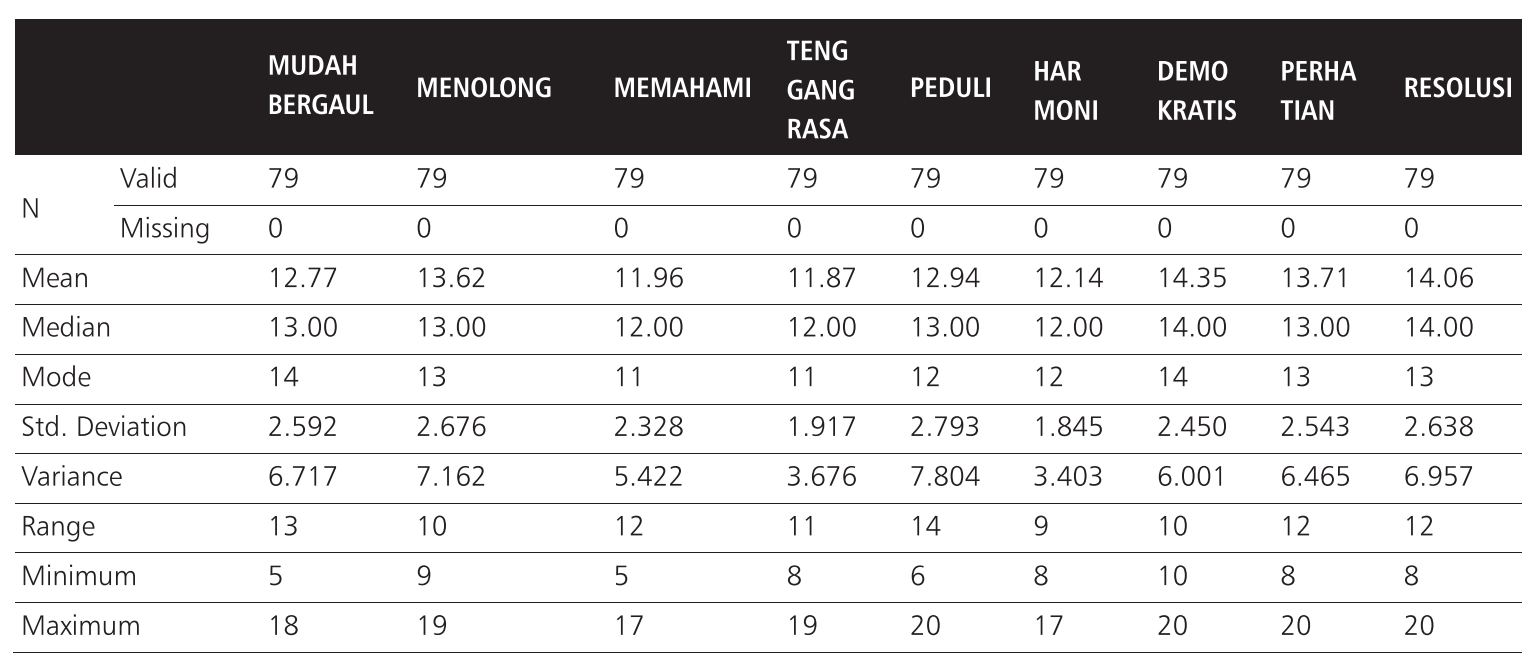

memahami orang lain masih lebih rendah dibanding kemampuan delapan dimensi yang lain. Dan kemampuan yang paling bagus dimiliki siswa adalah kemampuan berlaku demokratis, kemampuan menyelesaikan konflik dan disusul kemampuan perhatian pada orang lain.

\section{Perbedaan Ketrampilan Intrapersonal.}

Perbedaan ketrampilan intrapersonal siswa dapat dilihat dengan cara memperhatikan perbedaan jenis kelamin yang dianalisis dengan uji t (t-test) dan perbedaan tingkatan kelas, pekerjaan orang tua, dan urutan kelahiran anak dalam keluarga dilakukan uji beda dengan menggunakan ANNOVA one way.

Adapun hasil uji perbedaan kesembilan dimensi intrapersonal anak SD Negeri Kasihan Bantul yang meliputi dimensi sadar diri, percaya diri, menangani kelemahan diri, bertanggung jawab terhadap diri sendiri, membuka diri, tegas, berani mengambil keputusan sendiri, menangani stres, dan berani menyampaikan perasaannya.

Dilakukan dengang uji t. dengan melihat perbedaan jenis kelamin siswa, maka berdasarkan hasil dari Uji t, dapat diketahui bahwa terdapat perbedaan yang signifikan antara siswa laki-laki dan siswi 
perempuan pada semua dimensi ketrampilan intrapersonal yang meliputi sadar diri, percaya diri, menangani kelemahan diri, bertanggungjawab terhadap diri sendiri, membuka diri, tegas, berani mengambil keputusan sendiri, menangani stres, dan berani menyampaikan perasaannya. Berhubung semua dimensi intrapersonal memiliki taraf signifikansi lebih dari 0,05h, yang berarti Ho ditolak dan Ha diterima. Siswa laki-laki dan siswi perempuan memiliki cara yang berbeda dalam melihat dirinya sendiri. Siswa laki-laki cenderung lebih rasional dan siswi perempuan cenderung lebih emosional dalam melihat diri sendiri.

Sedangkan uji beda kemampuan intrapersonal dilihat dari perbedaan pekerjaan orang tua dengan menggunakan ANNOVA one way, maka dapat diperoleh hasil bahwa terdapat perbedaan ketrampilan intrapersonal yang meliputi sadar diri, percaya diri, kemampuan menangani kelemahan diri sendiri,bertanggung jawab, membuka diri, tegas, berani mengambil keputusan sendiri, menangani stres, dan keberanian menyampaikan perasaan antara siswa yang berasal dari keluarga PNS, Wiraswasta dan Petani. Semua dimensi menunjukkan bahwa nilai signifikansinya lebih dari 0,05h yang berarti Ho ditolak dan Ha diterima. Hal ini diasumsikan terdapat hubungan antar jenis pekerjaan orang tua dan cara mendidik anak yang berdampak pada perbedaan ketrampilan intrapersonal masing-masing anak dalam keluarga yang beda pekerjaan.

Perbedaan ketrampilan intrapersonal yang dilihat dari perbedaan tingkatan kelas di sekolah menunjukkan adanya perbedaan pada dimensi percaya diri, bertanggung jawab terhadap diri sendiri dan berani menyampaikan perasaan. Semakin tinggi tingkatan kelas siswa, maka ada kecenderungan semakin meningkat rasa percaya diri siswa, kemampuan bertanggung terhadap tugas yang dibebankan kepada siswa, dan karena sudah semakin senior seorang siswa cenderung semakin memiliki keberanian untuk menyampaikan perasaan. Begitu juga sebaliknya siswa yang kelasnya rendah akan merasa inferior, belum maksimal rasa tanggungjawabnya dan belum berani menyampaikan perasaannya pada orang lain.

Sedangkan pada dimensi sadar diri, kemampuan menangani kelemahan diri sendiri, membuka diri, tegas, berani mengambil keputusan sendiri, menangani stres tidak terdapat perbedaan antara pekerjaan orang tua dan ketrampilan intrapersonal siswa. Berdasarkan hasil perhitungan keenam dimensi tersebut menunjukkan taraf signifikasi kurang darai 0.05h yang berarti Ho diterima dan $\mathrm{Ha}$ ditolak. Ini berarti tidak terdapat perbedaan yang signifikan antara ketrampilan intrapersonal pada dimensi sadar diri, kemampuan menangani kelemahan diri sendiri, membuka diri, tegas, berani mengambil keputusan sendiri, menangani stres antara siswa kelas 4, 5 dan 6. Kondisi tersebut dapat dibuktikan pada hasil perhitungan SPSS pada tabel 3.

Selanjutnya untuk mengetahui perbedaan ketrampilan intrapersonal siswa yang dilihat dari urutan anak dalam keluarga dilakukan perhitungan dengan ANNOVA one way. Berdasarkan hasil uji beda dapat diketahui bahwa ketrampilan intrapersonal siswa yang meliputi sadar diri, percaya diri, menangani kelemahan diri, bertanggung jawab terhadap diri sendiri, membuka diri, tegas, berani 
TABEL 3. HUBUNGAN KETRAMPILAN INTRAPERSONAL DAN TINGKATAN KELAS

ANOVA

\begin{tabular}{|c|c|c|c|c|c|c|}
\hline & & $\begin{array}{l}\text { SUM OF } \\
\text { SQUARES }\end{array}$ & DF & MEAN SQUARE & $\mathbf{F}$ & SIG. \\
\hline \multirow[t]{3}{*}{ Sadardiri } & Between Groups & 412.825 & 2 & 206.412 & 56.690 & .000 \\
\hline & Within Groups & 276.720 & 76 & 3.641 & & \\
\hline & Total & 689.544 & 78 & & & \\
\hline \multirow[t]{3}{*}{ Percayadiri } & Between Groups & 10.551 & 2 & 5.276 & 1.103 & .337 \\
\hline & Within Groups & 363.423 & 76 & 4.782 & & \\
\hline & Total & 373.975 & 78 & & & \\
\hline \multirow[t]{3}{*}{ Refleksi } & Between Groups & 67.328 & 2 & 33.664 & 9.830 & .000 \\
\hline & Within Groups & 260.267 & 76 & 3.425 & & \\
\hline & Total & 327.595 & 78 & & & \\
\hline \multirow[t]{3}{*}{ Tgg Jwb } & Between Groups & 11.450 & 2 & 5.725 & 1.699 & .190 \\
\hline & Within Groups & 256.044 & 76 & 3.369 & & \\
\hline & Total & 267.494 & 78 & & & \\
\hline \multirow[t]{3}{*}{ Terbuka } & Between Groups & 81.725 & 2 & 40.863 & 7.845 & .001 \\
\hline & Within Groups & 395.870 & 76 & 5.209 & & \\
\hline & Total & 477.595 & 78 & & & \\
\hline \multirow[t]{3}{*}{ Tegas } & Between Groups & 58.640 & 2 & 29.320 & 5.452 & .006 \\
\hline & Within Groups & 408.702 & 76 & 5.378 & & \\
\hline & Total & 467.342 & 78 & & & \\
\hline \multirow[t]{3}{*}{ Berani } & Between Groups & 44.125 & 2 & 22.063 & 3.822 & .026 \\
\hline & Within Groups & 438.736 & 76 & 5.773 & & \\
\hline & Total & 482.861 & 78 & & & \\
\hline \multirow[t]{3}{*}{ Tegar } & Between Groups & 57.309 & 2 & 28.654 & 5.895 & .004 \\
\hline & Within Groups & 369.400 & 76 & 4.861 & & \\
\hline & Total & 426.709 & 78 & & & \\
\hline \multirow[t]{3}{*}{ Curhat } & Between Groups & 5.029 & 2 & 2.515 & .804 & .451 \\
\hline & Within Groups & 237.730 & 76 & 3.128 & & \\
\hline & Total & 242.759 & 78 & & & \\
\hline
\end{tabular}

mengambil keputusan sendiri, menangani stres, berani menyampaikan perasaan.

Berdasarkan perhitungan ANNOVA one way bahwa hanya ada satu dimensi ketrampilan intrapersonal yakni dimensi keterbukaan diri yang menunjukkan tidak terdapat perbedaan antara anak sulung,anak tengah dan anak bungsu dalam mensikapi keterbukaan diri. Asumsinya semua anak akan diperlakukan sama oleh orang tuanya, meskipun urutan lahirnya berbeda namun perilaku keterbukaannya bisa sama. Hasil perhitungan dengan SPSS menunjukkan taraf signifikansinya di bawah $0,05 \mathrm{~h}$ yang berarti tidak terdapat perbedaan ketrampilan intrapersonal pada dimensi keterbukaan diri antara anak sulung, anak tengah dan anak bungsu.

Sedangkan delapan dimensi yang lainnya selain keterbukaan yakni dimensi sadar diri, percaya diri, kemampuan menangani kelemahan diri sendiri, bertanggung jawab, tegas, berani mengambil keputusan sendiri, menangani stres, dan keberanian menyampaikan perasaan menunjukkan adanya perbedaan 
TABEL 4. HUBUNGAN KETRAMPILAN INTERPERSONAL DAN URUTAN ANAK DALAM KELUARGA

\begin{tabular}{|c|c|c|c|c|c|c|}
\hline & & $\begin{array}{l}\text { SUM OF } \\
\text { SQUARES }\end{array}$ & DF & MEAN SQUARE & $\mathbf{F}$ & SIG. \\
\hline \multirow[t]{3}{*}{ Bergaul } & Between Groups & 111.238 & 4 & 27.809 & 4.987 & .001 \\
\hline & Within Groups & 412.661 & 74 & 5.577 & & \\
\hline & Total & 523.899 & 78 & & & \\
\hline \multirow[t]{3}{*}{ Menolong } & Between Groups & 140.692 & 4 & 35.173 & 6.228 & .000 \\
\hline & Within Groups & 417.916 & 74 & 5.648 & & \\
\hline & Total & 558.608 & 78 & & & \\
\hline \multirow[t]{3}{*}{ Memahami } & Between Groups & 63.908 & 4 & 15.977 & 3.294 & .015 \\
\hline & Within Groups & 358.978 & 74 & 4.851 & & \\
\hline & Total & 422.886 & 78 & & & \\
\hline \multirow[t]{3}{*}{ Tenggang rasa } & Between Groups & 50.881 & 4 & 12.720 & 3.991 & .005 \\
\hline & Within Groups & 235.853 & 74 & 3.187 & & \\
\hline & Total & 286.734 & 78 & & & \\
\hline \multirow[t]{3}{*}{ Peduli } & Between Groups & 137.659 & 4 & 34.415 & 5.407 & .001 \\
\hline & Within Groups & 471.024 & 74 & 6.365 & & \\
\hline & Total & 608.684 & 78 & & & \\
\hline \multirow[t]{3}{*}{ Harmoni } & Between Groups & 38.518 & 4 & 9.630 & 3.140 & .019 \\
\hline & Within Groups & 226.950 & 74 & 3.067 & & \\
\hline & Total & 265.468 & 78 & & & \\
\hline \multirow[t]{3}{*}{ Demokratis } & Between Groups & 104.160 & 4 & 26.040 & 5.295 & .001 \\
\hline & Within Groups & 363.916 & 74 & 4.918 & & \\
\hline & Total & 468.076 & 78 & & & \\
\hline \multirow[t]{3}{*}{ Perhatian } & Between Groups & 101.235 & 4 & 25.309 & 4.646 & .002 \\
\hline & Within Groups & 403.069 & 74 & 5.447 & & \\
\hline & Total & 504.304 & 78 & & & \\
\hline \multirow[t]{3}{*}{ Resolusi } & Between Groups & 109.421 & 4 & 27.355 & 4.672 & .002 \\
\hline & Within Groups & 433.263 & 74 & 5.855 & & \\
\hline & Total & 542.684 & 78 & & & \\
\hline
\end{tabular}

ketrampilan intrapersonal pada anak sulung, tengah dan bungsu. Asumsinya adalah bahwa orang tua terkadang memperlakukan anak dengan cara berbeda. Anak sulung dipaksa cepat dewasa sementara anak bungsu disetting manja, anak tengah biasanya kurang diperhatikan tidak seperti anak sulung dan anak bungsu. Perbedaan pola asuh inilah yang dapat menyebabkan perbedaan kecenderungan keterbukaan. Anak bungsu cenderung kurang mandiri dan manja, sementara anak sulung cenderung suka mengatur dan berani mengambil keputusan. Sedangkan anak tengah cenderung tidak jelas sikapnya. Berdasarkan hasil perhitungan ANNOVA one way diperoleh nilai signifikansi diatas $0,05 \mathrm{~h}$ pada delapan dimensi tersebut. Hal ini menunjukkan bahwa Ho ditolak dan Ha diterima. Ini berarti bahwa terdapat perbedaan ketrampilan intrapersonal antara urutan anak dalam keluarga pada delapan dimensi yakni dimensi sadar diri, percaya diri, 
kemampuan menangani kelemahan diri sendiri, bertanggung jawab, tegas, berani mengambil keputusan sendiri, menangani stres, dan keberanian menyampaikan.

\section{Perbedaan Ketrampilan Interpersonal}

Perbedaan ketrampilan interpersonal siswa dapat dilihat dengan cara memperhatikan perbedaan jenis kelamin yang dianalisis dengan uji t (t-.test) dan perbedaan tingkatan kelas, pekerjaan orang tua, dan urutan kelahiran anak dalam keluarga dilakukan uji beda dengan menggunakan ANNOVA One Way.

Adapun hasil uji perbedaan kesembilan dimensi interpersonal anak SD Negeri Kasihan Bantul yang meliputi dimensi mudah bergaul, suka menolong, memahami orang lain, rasa peduli lingkungan, harmonis, demokratis, perhatian terhadap orang lain, dan trampil dalam menyelesaikan konflik, dilakukan dengan uji t dengan melihat perbedaan jenis kelamin siswa.

Berdasarkan hasil Uji t dapat diketahui bahwa terdapat perbedaan yang signifikan antara siswa dan siswi pada semua dimensi ketrampilan interpersonal yang meliputi: mudah bergaul, suka menolong, memahami orang lain, rasa peduli lingkungan, harmonis, demokratis, perhatian terhadap orang lain, dan trampil dalam menyelesaikan konflik. Semua dimensi dalam ketrampilan interpersonal memiliki taraf signifikansi lebih dari 0,05h, yang berarti Ho ditolak dan $\mathrm{Ha}$ diterima. Hal ini berarti bahwa siswa laki-laki dan siswa perempuan memiliki cara yang berbeda dalam berinteraksi dengan orang lain. Siswa laki-laki cenderung lebih rasional dan siswa perempuan cenderung lebih emosional dalam melakukan komunikasi dengan orang lain.
Sedangkan uji beda kemampuan interpersonal dilihat dari perbedaan jenis pekerjaan orang tua dengan menggunakan ANNOVA one way, maka dapat diperoleh hasil terdapat perbedaan ketrampilan interpersonal yang meliputi: mudah bergaul, suka menolong, memahami orang lain, rasa peduli lingkungan, harmonis, demokratis, perhatian terhadap orang lain, dan trampil dalam menyelesaikan konflik antara siswa yang berasal dari keluarga PNS, Wiraswasta dan Petani. Semua dimensi menunjukkan bahwa nilai signifikansinya lebih dari $0,05 \mathrm{~h}$ yang berarti Ho ditolak dan Ha diterima. Hal ini berarti terdapat hubungan antar jenis pekerjaan orang tua dan cara mendidik anak yang berdampak pada perbedaan ketrampilan interpersonal masing-masing anak dalam keluarga yang berbeda pekerjaannya.

Perbedaan ketrampilan interpersonal yang dilihat dari perbedaan tingkatan kelas di sekolah menunjukkan adanya perbedaan pada dimensi memahami orang lain dan tenggang rasa. Semakin tinggi tingkatan kelas siswa, maka ada kecenderungan semakin meningkat pemahamannya pada orang lain karena sudah lebih berpengalaman dalam bergaul. Kemampuan bersikap tenggang rasa (sikap peduli pada lingkungan) juga akan lebih mantap pada kelas atas karena sudah akrab dan tumbuh semangat solidaritasnya. Begitu pula sebaliknya siswa yang kelasnya rendah akan merasa inferior, belum bisa memahami orang lain, masih bersikap individualis belum bisa tenggang rasa pada orang lain.

Sedangkan pada dimensi mudah bergaul, suka menolong, harmonis, demokratis, perhatian terhadap orang lain, dan trampil dalam menyelesaikan konflik tidak terdapat 
perbedaan antara pekerjaan orang tua dan ketrampilan interpersonal siswa. Berdasarkan hasil perhitungan ketujuh dimensi tersebut menunjukkan taraf signifikasi kurang dari 0.05 h yang berarti Ho diterima dan $\mathrm{Ha}$ ditolak. Ini berarti bahwa tidak terdapat perbedaan yang signifikan ketrampilan interpersonal dalam dimensi mudah bergaul, suka menolong, harmonis, demokratis, perhatian terhadap orang lain, dan trampil dalam menyelesaikan konflik antara siswa kelas 4, kelas 5, dan kelas 6.

Selanjutnya untuk mengetahui perbedaan ketrampilan interpersonal siswa yang dilihat dari urutan anak dalam keluarga dilakukan perhitungan dengan ANNOVA one way dan mendapat hasil sebagai berikut:

(lihat tabel 4)

Berdasarkan hasil uji beda pada tabel tersebut di atas diketahui bahwa ketrampilan interpersonal siswa yang dimensinya meliputi: mudah bergaul, suka menolong, memahami orang lain, rasa peduli lingkungan, harmonis, demokratis, perhatian terhadap orang lain, dan trampil dalam menyelesaikan konflik. Berdasarkan perhitungan ANNOVA one way bahwa semua dimensi ketrampilan interpersonal tidak terdapat perbedaan antara anak sulung, anak tengah dan anak bungsu dalam ketrampilan berinteraksi dengan orang lain. Hal ini berarti bahwa semua anak akan diperlakukan sama oleh orang tuanya. Meskipun urutan lahirnya berbeda namun perilaku keterampilan berkomunikasi dengan orang lain bisa sama. Hasil perhitungan dengan SPSS menunjukkan bahwa semua dimensi memperoleh nilai taraf signifikansinya di bawah 0,05h yang berarti tidak terdapat perbedaan ketrampilan interpersonal pada semua dimensi antara anak sulung, anak tengah dan anak bungsu.
Meskipun ada asumsi bahwa orang tua terkadang memperlakukan anak dengan cara berbeda, anak sulung dipaksa cepat dewasa sementara anak bungsu disetting manja, anak tengah biasanya kurang diperhatikan tidak seperti anak sulung dan bungsu. Namun ternyata hasil pendidikan tentang cara berkomunikasi dengan orang lain adalah tidak terdapat perbedaan kemampuan interpersonal pada semua dimensi. Berdasarkan hasil perhitungan ANNOVA one way diperoleh nilai signifikansi dibawah 0,05h pada sembilan dimensi tersebut. Hal ini menunjukkan bahwa Ho diterima dan $\mathrm{Ha}$ ditolak. Ini berarti bahwa tidak terdapat perbedaan ketrampilan interpersonal antara urutan anak dalam keluarga pada sembilan dimensi yaitu: mudah bergaul, suka menolong, memahami orang lain, rasa peduli lingkungan, harmonis, demokratis, perhatian terhadap orang lain, dan trampil dalam menyelesaikan konflik.

\section{KESIMPULAN}

Penelitian ini menyimpukan, Ada 9 dimensi intrapersonal yakni sadar diri, percaya diri, menangani kelemahan diri, bertanggung jawab terhadap diri sendiri, membuka diri, tegas, berani mengambil keputusan sendiri, menangani stres, dan berani menyampaikan perasaannya. Kemampuan yang paling rendah pada dimensi percaya diri, sedangkan kemampuan yang paling menonjol adalah dimensi keberanian menyampaikan perasaan pada orang lain. Sementara 9 dimensi intrapersonal meliputi mudah bergaul, suka menolong, memahami orang lain, tenggang rasa, peduli lingkungan, harmonis, demokratis, perhatian terhadap orang lain, dan trampil menyelesaikan konflik. Dimensi 
kemampuan yang paling rendah adalah kemampuan memahami orang lain. Kemampuan yang paling menonjol adalah kemampuan berlaku demokratis dan kemampuan menyelesaikan konflik serta kemampuan perhatian pada orang lain. Terdapat perbedaan ketrampilan intrapersonal berdasar jenis kelamin dan pekerjaan orang tua pada semua dimensi. Tingkatan kelas hanya berbeda di 3 dimensi Intrapersonal yakni percaya diri, tanggung jawab, keberanian menyampaikan perasaan. Urutan anak dalam keluarga hanya satu dimensi yang tidak berbeda yakni dimensi keterbukaan. Terdapat perbedaan Ketrampilan interpersonal berdasar jenis kelamin dan pekerjaan orang tua pada semua dimensi. Perbedaan berdasar tingkatan kelas hanya pada dimensi memahami orang lain dan tenggang rasa. Tidak terdapat perbedaan antara anak sulung, anak tengah dan anak bungsu dalam ketrampilan berinteraksi dengan orang lain.

Berdasarkan kesimpulan tersebut di atas, maka terdapat beberapa hal yang perlu disarankan yaitu: (1).Guru perlu membiasakan pada siswa untuk bisa trampil dalam memahami diri sendiri melalui pembelajaran bermakna, sehingga memunculkan kesadaran untuk berbuat baik tanpa merasa terpaksa. (2).Kemampuan berkomunikasi dan berinteraksi siswa perlu sering dilatih agar kelak mampu mengatasi masalah sosial (social problems) dalam kehidupan. Guru perlu mengajarkan bagaimana cara bersosialisasi dengan orang yang berbeda agama dan berbeda status sosialnya.(3).Guru perlu mengajarkan dan membiasakan untuk menengok teman yang sakit, memberi contoh cara menghibur teman yang sedih.

\section{CATATAN AKHIR}

Kurikulum SD, 2011:3.

2 Zamroni, Pengembangan Sistem Penilaian Pendidikan yang menerapkan KBK dalam Kerangka Otonomi Daerah (Yogyakarta: HEPI, 2005), h. 49.

3 Maurice \& Roger dalam Larry P.Nucci, Handbook of Moral and Character Education, (New York and London: Routledge, 2008), h. 250.

4 Kemendiknas tahun 2011, h. 243-252.

5 Howard Gardner, Frames of Mind: The Theory of Multiple Intelligence, (New York: Basic Books, 1993), h. 24-25.

6 Daniel Goleman, Emotional Intelligence, Terj: T.Hermaya, (Jakarta: Gramedia, 2005), h. 52.

7 Collin Rose and Malcolm J. Nicholl, Accelerated Learning for the $21^{\text {st }}$ Century, Terj: Dedy Ahimsa. (Bandung: Nuansa, 2002), h. 60

8 Alistair Mant, Intelligent Leadership, (New South Wales: Allen \& Unwin. 1997 ), h. 161.

9 May Lwin et al, How to Multiply Your Child's Intelligence. Terj: Christine S. (Jakarta: Indeks, 2005), h. 233.

10 Jordan E. Ayan, AHA!: 10 Ways to Free Your Creative Spirit and Find Your Great Ideas, Terj: Ibnu Setiawan (Bandung: Mizan, 2003), h. 40.

11 David Lazear, Pathways of Learning: Teaching Students and Parents about Multiple Intelligences, (Arizona: Zephyr, 2000), h. 24.

12 William G. Cunningham and Paula A.Corderio, Educational Leadership: A Problem Based Approach (Boston: Pearson Education, 2003), h. 205.

13 Howard Gardner, Frames of Mind, h. 239.

14 Alistair Mant, Intelligent Leadership, h. 161.

15 David Lazear, Pathways of Learning, h. 23.

16 William G. Cunningham and Paula A.Corderio, Educational Leadership, h. 205.

17 Jordan E. Ayan, AHA!: 10 Ways to Free Your Creative Spirit, h. 125

18 May Lwin et al, How to Multiply Your Child's Intelligence, h. 197.

\section{DAFTAR PUSTAKA}

Amstrong, T. 1994. Multiple Intelligences in The Classroom. Virginia: ASCD

Anderson,L.W. 1981..Assessing Affective Characteristics in the Schools.Boston: Allyn and Bacon.

Ayan, Jordan E. 2003. AHAl: 10 Ways to Free Your Creative Spirit and Find Your Great Ideas, Terj: Ibnu Setiawan, Bandung: Mizan.

Coopersmith, Stanley. 1986. Self-Esteem Inventory, Palo Alto, California: Consulting Psychologist Press.

Cunningham, William G. and Paula A.Corderio. 2003. Educational Leadership: A Problem Based Approach. Boston: Pearson Education.

David A.Whetten.,Kim S.Cameron. 1991. Developing Management Skills, New York: Harper Collin Publishers. 
Diknas, RI. 2004. Kurikulum SD/MI berdasarkan KTSP, Jakarta: Puskur Diknas.

Gardner, Howard. 1993. Frames of Mind: The Theory of Multiple Intelligence, New York: Basic Books.

Goleman, Daniel. 2005. Emotional Intelligence, Terj: T.Hermaya, Jakarta: Gramedia.

Hurlock, Elizabeth B. 1991. Perkembangan anak. (Terj: Metasari dan Tjandrasa dan Muslichah Zarkasih. Jakarta: Erlangga.

Karen E,Bohlin. 2005. Teaching character Education Through Literature, Awakening the Moral Immagination Secondary Classrooms. New York: RoutledgeFalmer.

Kilpatrick. 1992. Why Johny can't tell right or wrong, and what we can do about it. New York: A Touchstone Book.

Kirschenbaum,H. 1995. Enhance Values and Morality in Schools and Youth, Setting. Boston: Allyn and Bacon.

Kohlberg, Lawrence, (terj) John de Santo, Tahap-Tahap Perkembangan Moral, Yogyakarta: Kanisius.

Larry P.Nucci, 2008. Handbook of Moral and Character Education, New York and London: Routledge.

Lazear, David. 2000. Pathways of Learning: Teaching Students and Parents about Multiple Intelligences. Arizona: Zephyr.

Lickona, Thomas. 1992. Educating for character, how our schools can teach respect, Respect and Responsibility, New York: Bantam Books.

1975. Moral Development and Behaviour:

Theory, research, and Social Issues. New York: States University of New York.

Lwin, May et al. 2005. How to Multiply Your Child's Intelligence. Terj: Christine S. Jakarta: Indeks.

Mant, Alistair. 1997. Intelligent Leadership, New South Wales: Allen \& Unwin.

Piaget,]. (1950. The Psychology of Intelligence, New York: Harcourt, Brace\&World.

Pusat Bahasa Depdiknas. 2005. Kamus Besar Bahasa Indonesia, Edisi ke III. Jakarta: Balai Pustaka.

Ratna Megawangi. 2004. Pendidikan karakter: Solusi yang tepat untuk membangun bangsa. Jakarta: Star Energy (Kakap) Ltd.

Rohendi. 2004. "Moral yang tereliminasi." Pikiran Rakyat 15 Juli 2004.

Rose, Collin and Malcolm J. Nicholl. 2002. Accelerated Learning for the $21^{\text {st }}$ Century, Terj: Dedy Ahimsa. Bandung: Nuansa.

Sax,G. 1980. Principles of educational psychological measurement and educational an evaluation. Balmont, CA: Wadswort Publising Co.

Schon, D. 1990. Educating the reflective practitioner. Artikel. Diambil pada tgl 12 Desember 2010, dari http://www.reflectiveaction.com/home.html.

Sudarminta. 2002. Pendidikan dan Pembentukan Watak yang Baik, Dalam Tilaar: Pendidikan untuk Masyarakat Indonesia Baru, Jakarta: Grasindo.

Tadkiratun Musfiroh. 2008. Character Building, Yogyakarta:
Tiara Wacana.

Tilaar, HR. 2006. Pembangunan watak dan karakter dengan penciptaan kultur sekolah, Kompas, 8 Maret p.12.

Zamroni, 2005. Pengembangan Sistem Penilaian Pendidikan yang menerapkan KBK dalam Kerangka Otonomi Daerah. Yogyakarta: HEPI.

Zuchdi, Darmiyati. 2010. Humanisasi Pendidikan, Menumbuhkan Kembali Pendidikan yang Manusiawi, Jakarta: Bumi Aksara. 2009. Pendidikan Karakter, Grand Design dan Nilai-Nilai Target, Yogyakarta: UNY Press. 